has nothing-as Mitchell asserted-to do with its solubility or compressibility. Fust as little practicable is the chemical hypothesis upon what takes place in caoutehouc, and the absorption of gases such as nitrous oxide, carbonic acid, and hydrogen by caoutchouc must be considered as a purely physical phenomenon. A layer of caoutchoue is, then, to be conceived as a porous substance, endowed with powers of condensing as well as of rarefying gases whose porosity is of the same order as the porosity of graphite. The motion of the gas takes place through the pores of the caoutchouc.

It is much to be regretted that Grahan's experiments upon the passage of gases through metals were so conducted, that they cannot now be calculated with the help of the laws of the diffusion of gases in absorbent substances. I have been able to calculate only those numbers which, as they are not without interest, I will here communicate. They are the constant $D$ for hydrogen in platinum at bright red heat, and $D$ for carbonic oxide and hydrogen in iron at full red heat.

A platinum wire absorbed at red heat $0^{\circ} 17$ volumes of hydro. gen (taking the average of four experiments). A tube drawn out of the same mass of fused platinum, $0^{\prime}$ i 1 centimetres in diameter, let $489^{\circ} 2$ cubic centimetres of gas in the minute pass through a surface of I square metre; therefore

$$
D=0.00053 \frac{\mathrm{cm}^{2}}{\mathrm{sec}} \text {. }
$$

A tube of malleable iron, 0.17 centimetres in diameter, let 0.284 cubic centimetres of carbonic oxide and $76.5 \mathrm{cubic}$ centimetres of hydrogen through the square metre in the minute. Since one volume of this metal can contain four volumes of carbonic oxide, so is for this gas

$$
D=0.00000002 \frac{\mathrm{cm}^{2}}{\mathrm{sec}} \text {. }
$$

Since the coefficient of absorption of this metal for hydrogen was less than four, so is the constant $D$ for this gas greater than $0.00000054 \frac{\mathrm{cm}^{2}}{\mathrm{sec}}$, whence it follows, if there can be any comparison between these two numbers, that in metals greater constants $D$ belong to specifically lighter gases.

It has lately been asserted by Stefan that the constant $\mathcal{D}$, in both water and alcohol, is greater for oxygen and nitrogen than for carbonic acid, and that the greatest constant pertains to hydrogen. It would be, however, premature to wish to draw from his experiments any conclusions with regard to the nature of absorption of gases in fluids.

Franz Exner has already shown, several years ago, that, on the passage of gases through a lamina consisting of a solution of soap in water, the interchanged volumes of two gases are directly proportional to their coefficients of absorption and in inverse ratio to the square root of their specific gravities. Hence Stefan has concluded that the constant $D$ in fluids is in inverse ratio to the square root of the specific gravity of the gas, and that the gas molecules move by themselves and not in connection with the molecules of the fluid, which would correspond with Dalton's views on the nature of absorption in fluids. Meanwhile, these conclusions are contradicted by the experiments of Pranghe, who has shown that the above-mentioned relation in the case of the lamina is not at all borne out when pure unboiled linseed oil is used. We see from this, then, that what takes place in the case of fluids must be much more complicated, and that we must subject the matter to a much more searching and extended inquiry before we shall be in a position to say anything definite upon the nature of the absorption of gases in liquids.

S. WROBLEWSKI

\section{NOTE ON PREHISTORIC STATIONS IN CARNIOLA}

THE most important of these prehistoric stations is the burialfield of Klenik, near Waatsch. During the year 1878 about 250 graves, covered with stone slabs, were opened at a depth of from $\frac{1}{2}$ metre to $2 \frac{1}{2}$ metres. They contained skeletons, some remains of burnt corpses, and a great number of various objects. The bronze and other articles are very similar to those found in the well-known cemetery near Hallstadt, in Upper Austria. No Roman remains were met with. Thus there is no doubt of the pre-Roman age of these stations and cemeteries near

${ }^{x}$ From the First Report of the Prehistorical Committee of the Vienn Academy, with 22 plates. By F. von Hochstetfer and Ch. Deschmann. (Procedings, Imper. Acad, July 3, 1879.)
Waatsch. They may be ascribed with great probability to the Taurisci, a Celtic tribe, known to have worked the salt at Hallstadt, and to have extended from Upper Austria, through Styria and Carinthia, as far as the Julian AIps. Strabo asserts explicitly that the very ancient landing-place Nauportus (now Ober-Laibach) was a settlement of this people, and, according to him, Italian merchandise was brought by carriage from Aquileja over Mount Okra (now Birnbaumer Wald), then by the River Savus to Siscia (now Sissek) and the Danubian districts. Thus it must be admitted that before the reign of Augustus a much-used water-communication existed on the Save and the Laibach between Siscia and Nauportus. The tradition ascribing the foundation of Emona to the Argonauts is an indication of the very remote beginning of this intercourse. Prof. Muillner, of Marburg, has lately offered sorne forcible arguments to the effect that Emona did not occupy the present position of Laibach, but was at the south end of the Laibach Moor, where Brundorf and Sonnegg now stand.

The graves, with skeletons, at Rojé, near Morants, contain objects referable to the Merovingian Period (fourth to seventh centuries) ; and a skull from one of them is of the type of those found in the successional sepultures.

\section{GEOLOGY OF GREECE}

I. The Thessatian Olympus.-In treating of the geology of Greece, as determined by a recent survey, Herr M. Neumayr, in the Proceed. Imper. Acad. Sciences, Vienna, July 17, 1879, describes this mountain-group as having a north and south direction, and consisting of a somewhat flattened dome of strata, with a subordinate syncline on the west. The limits on both sides are defined by lines of fracture. The constituent rocks are schists, of many kinds, with enormous intercalated limestones, at some places 3,000 metres thick. These latter are partly saccharoidal, partly semicrystalline, and sometimes nearly compact. In the last variety there are, in some localities numerous indeterminable organic remains.

2. M. Neumayr and L. Burgerstein state that the broad peninsular mass in South Roumelia, below Salonica, known as Chalkidiké (Chalcidica), is for the most part composed of micaceous and other schists, excepting its south-west portion and the Athos promontory. At some places considerable beds of marble are intercalated. The middle promontory of the three terminating the great peninsula is called Longos, and consists of gneiss, the oldest rock of the region.

3. The Island of Cos, according to Neumayr, consists for the most part of schists, marble, and Hippurite-limestone (with Rudistæ). The remainder is occupied by upper tertiary and diluvial deposits. Of the tertiaries the lower pliocene paludina beds strikingly resemble, in their fauna, the analogous Sclavonian deposits, and over them lie marine pliocene beds and rhyolitic tuffs; and eruptive rocks, trachytic in character, are also present. Being the extreme eastern member of the CycladoSporadic series, traversing the Egean, and being connected with the neighbouring volcanic islands, Cos is well adapted to afford an insight into the nature of this submarine mountain-chain, and it yields an.indication of the South-Egean basin being a depressed area of diluvial origin. The freshwater pliocene fauna offers interesting materials for the discussion of the upper tertiary freshwater deposits of the Egean region at present known, and of the evolution of the Eastern Mediterranean area. A number of passages have been collected by Prof. Hörnes from the Greek Classics, mentioning "giants' bones," which may point to places where remains of fossil mammals have been found.

\section{NOTES FROM NEW ZEALAND}

Wild Pigs and Wekas (Ocydromus).-Early in the spring of $1876 \mathrm{I}$ spent several days in fern-collecting and botanising in the Malvern Hills district of Canterbury. Whilst so engaged, in many places I came across fresh pig-tracks and rootings, now and then sighting a boar. On one open hillside, bordered with fagus woods, I found three nests of that curious rail, the weka (Ocydromus); each of the nests contained eggs. It seemed remarkable that the nests should have remained unravaged by the wild pigs that were constantly roaming about the neighbourhood. It is highly improbable that the keen-scented swine were not aware of the weka's haunts. The trail of this bird is strong, readily followed by dogs; indeed, dogs take to this pursuit with so much of pleasure and relish that many good sheep-dogs 